\title{
Preliminary Report on Development of Coating for Alloy Case
}

\author{
P. B. Archibald
}

\section{DISCLAIMER}

This report was prepared as an account of work sponsored by an agency of the United States Government. Neither the United States Government nor any agency thereof, nor any of their employecs, makes any warranty, express or implied, or assumes any legal liability or responsibility for the accuracy, completeness, or usefulness of any information, apparatus, product, or process disclosed, or represents that its use would not infringe privately owned rights. Reference herein to any specific commercial product, process, or service by trade name, trademark, manufacturer, or otherwise does not necessarily constitute or imply its endorsement, recommendation, or favoring by the United States Government or any agency thereof. The views and opinions of authors expressed herein do not necessarily state or reflect those of the United States Government or any agency thereof.

\section{OSTI}

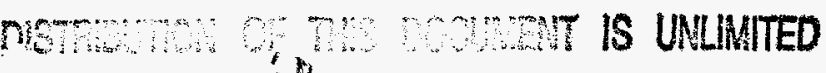

July 27, 1956

This is an informal report intended primarily for internal or limited external distribution. The opinions and conclusions stated are those of the author and may or may not be those of the Laboratory.

Work performed under the auspices of the U.S. Department of Energy by the Lawrence Livermore National Laboratory under Contract W-7405-ENG-48.

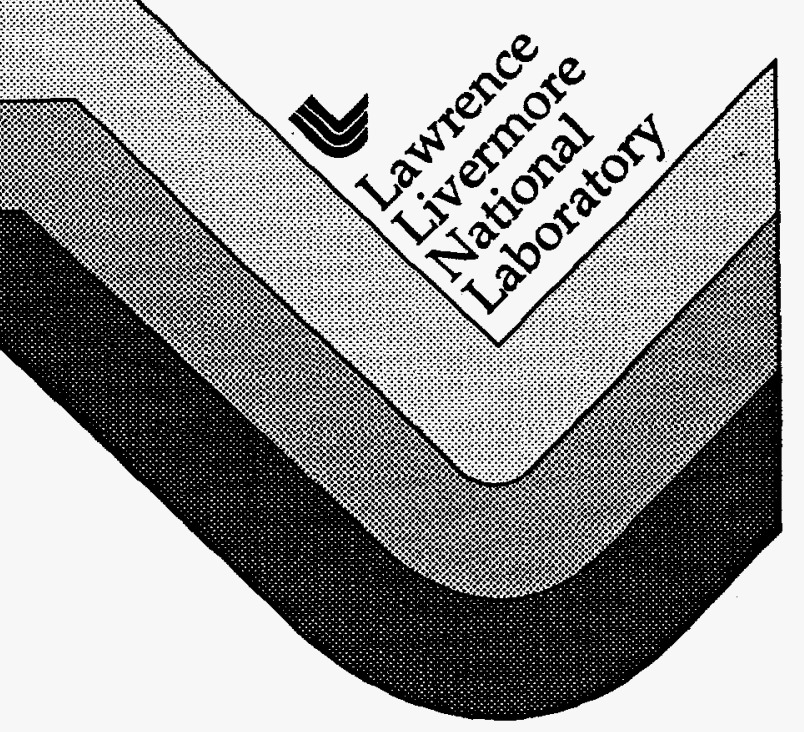




\section{DISCLAMMER}

Portions of this document may be illegible in electronic image products. Images are produced from the best available original document. 


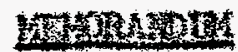

To8

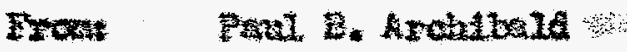

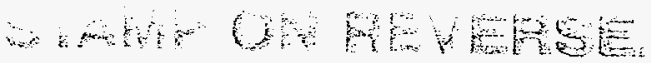

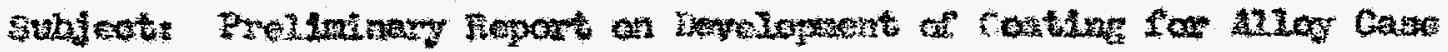

56ax

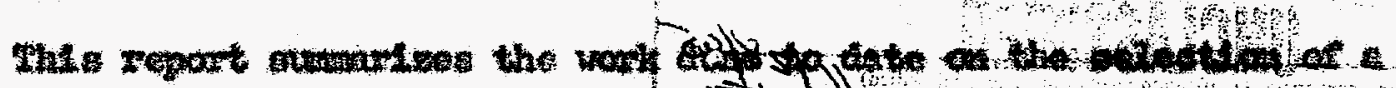

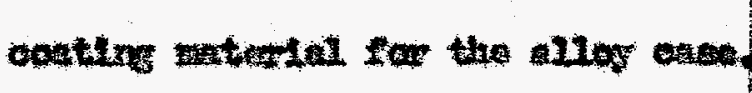

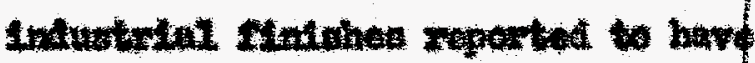

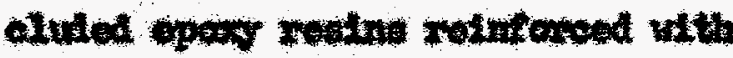

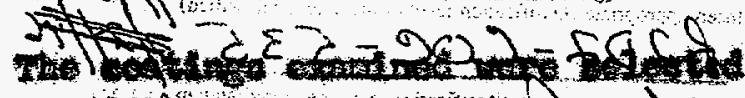

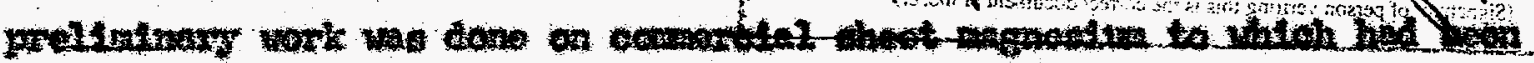

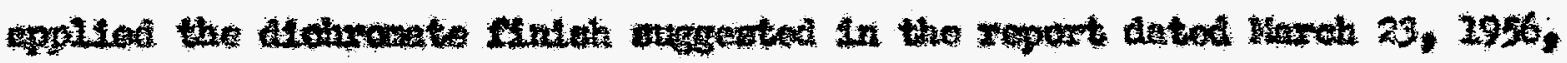
1. Hat.

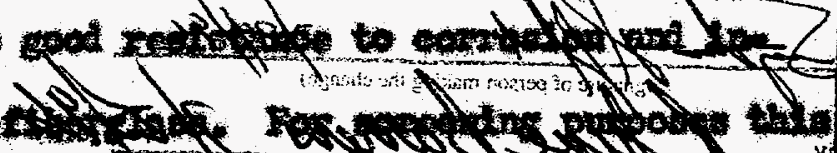

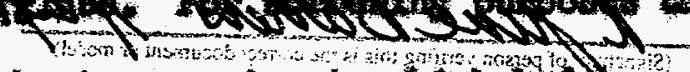

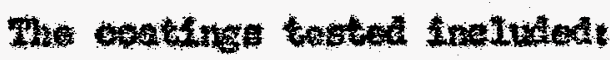

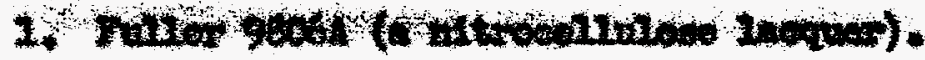

2. 100

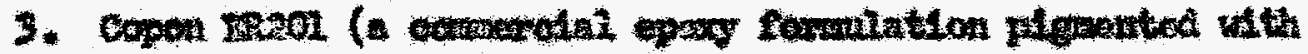
red 1ead).

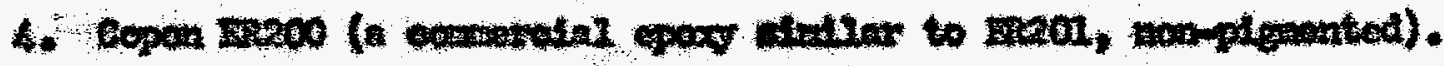

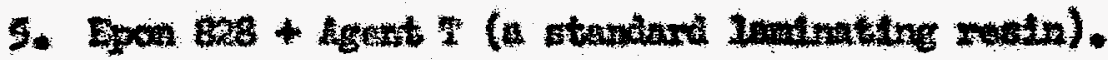

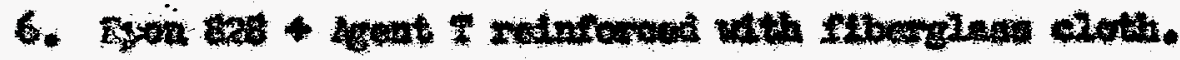

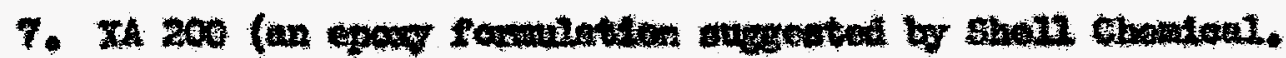

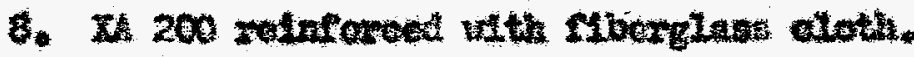

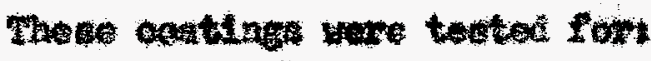

A. Dot Restistance.

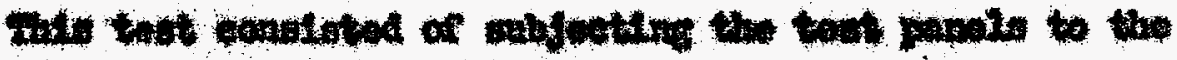

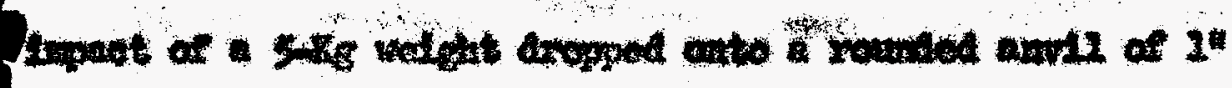

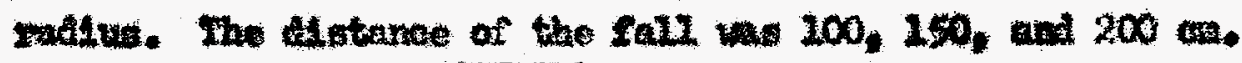




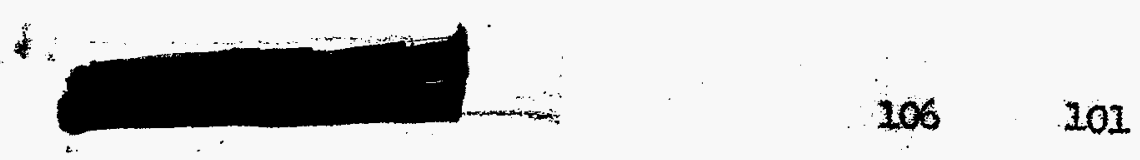

Barney Rubin $-2-$ July 27,1956

The photograph ettached (P1ate $I_{\text {. }}$ ) shows the results of this test. The two Iower marke on each penel were made at $100 \mathrm{~cm}$, the two centier marics at $150 \mathrm{~cm}$, and the upper maxks vere mace at $200 \mathrm{~cm}$.

D. Corrosian Fiesistance.

This test consisted of the alternate imersion test ham $B$ 192-44T. The reauts of thia test are shown in PIate II. (The holes in the panels vere punched after the coating vas applied.) The panels were tested for 200 hours.

c. Abrostion Restatanee:

This teat, whon is compsrative only, constated of exposing the test panols to a mall and bloster at a constant atstanoe for various lengths of the. Whe resulta of this test are shown in Plate III.

D. Thermal shools posistance.

This test consisted of exposing the test penels to alternate terperatures of $-65^{\circ}$. and $165^{\circ} \mathrm{F}$. The test was for four oyeles.

\section{Aesplts}

Iropet Rosistange

Under the condittens of the test previously described, the comercigl opoxy formitations stand very well, es does the 200 formitation zuggested by Shell Chemicel 6o. The nitrocellulose Iacquer (Fuller g806A) and the feoprene $1-700$ appear to be crushed, although the damge is restricted to the ares of 1mpat. The Epon 828, both with and without glasseloth

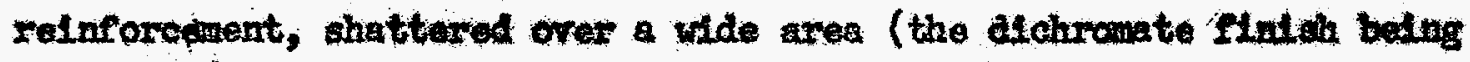
acturily pulled frow the gnestum panel). 


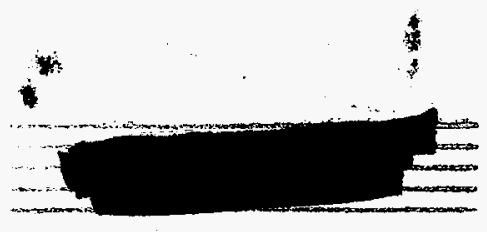

Babsioy Aubla

Comrogion Resistance

Under the conditions of the test the ppary costings appeared to be superior to the nitrocellulose and rery much superfor to the neoprene coating.

\section{Abragion Resistanos}

In this test an attempt was to obtain an eroded spot of approximately the same alue by varying the tine of exposure. Hinder auch a method the neoprene coating lasted mach longer than the other costings tested, whilo the epoxy costings lasted longer then the nitrocellulose.

Tiemal shock

None of the specimene tegted showed any visible sign of fajlure, w th the exception of the neoprene coating uhich developed a glight tack.

\section{Gonclustong}

on the basls of the foregoing, it was decided to tegt the following coatings on a.lloy speeimens:

Fuller 98064

Copon wen

Neoprene N-700 with an undercont of Copon $18 R 201$

Hitrodur (a comercial epoxy which was not Included in the inftial tests).

The selection of the epoxy Copon fr 201 for further testing was based on 
Bamey Ruld

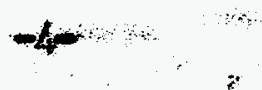

Tw1y 27, 1956

the necessity of Ifming the number of spectmens and the general

practice of using pigrented paints for corroston resistance.

The use of a single layen of glass oloth as a reinforcenent is

definftely eliminated. It is planned to make a test laminate of several

layere of glass cloth and to form it onto a motal ahape with contours stmilar to the sotalal dise.

Paul B. Archibala

Distributiona
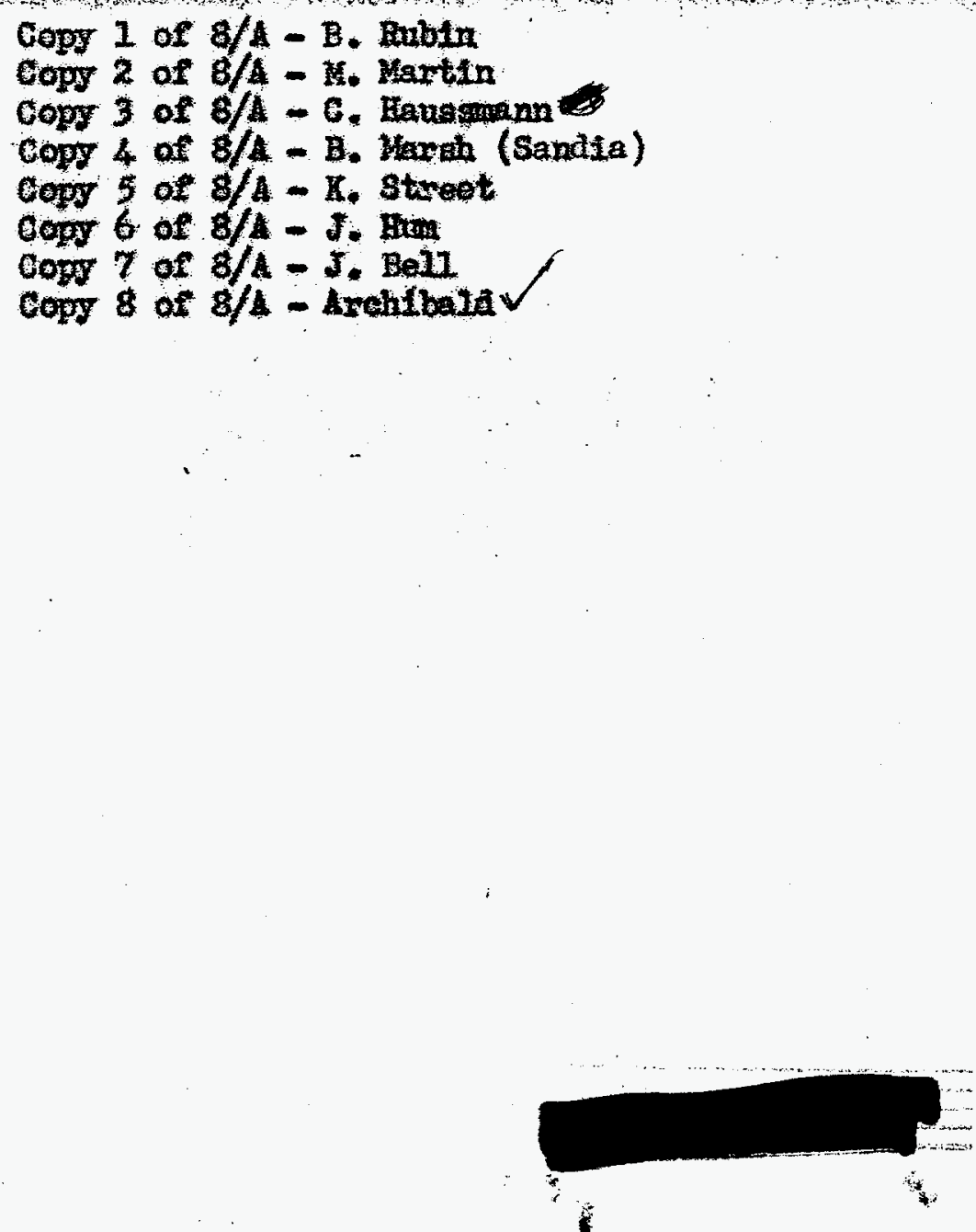